Cain, A. J., And currey, J. D. 1963. Area effects in Cepaea. Phil. Trans. Roy. Soc. Lond., B, $246,1-81$.

CAIN, A. J., AND Sheppard, P. M. 1954. Natural selection in Cepaea. Genetics, 39, 89-116.

CAIN, A. J., ShePpard, P. M., AND KING, J. M. B. 1968. Studies on Cepaea I. The genetics of some morphs and varieties of Cepaea nemoralis (L). Phil. Trans. Roy. Soc. Lond., B, 253, 383-396.

CAMERON, R. A. D., AND REDFERN, M. 1972. The terrestrial Mollusca of the Malham area. Field Studies, 3, 589-602.

CLARKE, B. 1962. Balanced polymorphism and the diversity of sympatric species. In Taxonomy and Geography (ed. D. Nichols), Systematics Association pub., 4, 47-78.

JONES, J. s. 1973. Ecological genetics and natural selection in molluscs. Science, 182, 546-552.

PARKIN, D. T. 1971. Visual selection in the landsnail Arianta arbustorum (L.). Heredity, 26, $35-47$.

QUenouille, M. H. 1950. Introductory Statistics. Pergamon Press, London.

SHEPPARD, P. M. 1951. Fluctuations in the selective value of certain phenotypes in the polymorphic landsnail Cepaea nemoralis (L.). Heredity, 5, 125-134.

TAYLOR, J. W. 1916. Monograph of the Land and Freshwater Mollusca of the British Isles. Taylor Bros., Leeds.

\title{
THE EFFECT OF ENVIRONMENT ON HERITABILITY AND PREDICTED SELECTION RESPONSE: A REPLY
}

\author{
J. M. RENDEL and F. E. BINET \\ Division of Animal Genetics, C.S.I.R.O., P.O. Box 90, Epping, N.S.W. 2121, Australia
}

Received 18.ii.74

DADAy et al. (1973) examined the possibilities of selection for the genetic improvement of some economic characters of Medicago sativa $(\mathrm{L})$ in different environments, with a view to applying Hammond's ideas that a character will be most easily advanced by selective breeding in the environment in which it is most fully expressed.

Hammond's idea applies to two sets of conditions. When a genotype is too weak to express itself in the environment in which it is to be used, but will do so if the frequency of relevant alleles is increased, selection for the character concerned in circumstances in which the genotype is expressed will increase gene frequencies to the point where the genes are expressed in the original environment also. This is essentially the finding of Waddington's (1952) experiment with crossvein-less in Drosophila melanogaster. There have been numerous examples published since. A convenient illustration is the selection for the ability of rabbits to acquire immunity to myxoma virus. Unselected populations of rabbits exposed to virulent strains of virus suffered such a high mortality that virtually all infected rabbits died and hence there was no selection in favour of the better genotypes. However, when populations are exposed to strains with a case mortality of 90 per cent or less, survival of the better genotypes rapidly gives rise to populations in which there is some survival of individuals even after exposure to the more virulent strains (Sobey, 1969). Genetic variation, which is latent in one régime, is exposed and used by selection in a second, until eventually the genotype achieves expression in the first. 
In the second set of conditions, the character is expressed in both environments but to a different degree. Genetic advance will be most rapid when selection differential $\times$ heritability is greatest. If the genotype to be selected is less well expressed in the environment in which it is to be used, its genetic advance will be more rapid when it is selected in the other. Hammond's idea will apply whenever heritability is highest in populations whose phenotypic variance is highest. Heritability by itself may be no guide to the outcome. Variances may differ in the two environments for both genetic and environmental reasons. It is quite possible for heritability to be less and total variance more in one environment in such a way that selection differential $\times$ heritability is greater in the environment in which heritability is less.

In Daday et al. (loc. cit.), differences in heritability are positively associated with those in total phenotypic variance: this shows that higher heritabilities are due (inter alia) to higher genetic variance. This finding seems to strengthen optimistic forecasts for the achievement of the aims of Hammond's recommendations; however, it also indicates that some of the alleles selected for are not expressed in the poorer environments. This suspicion is an additional indication of the need for a more detailed biometrical analysis of the material from which the genetic correlations (Daday et al., loc. cit.; Daday, 1965) were obtained, an analysis which, it is hoped, will be published shortly elsewhere.

Conclusions to be drawn from statistical analyses depend upon the observable metric being an expression of substantially the same phenotype in the two environments. Resistance to avirulent viruses must imply resistance to virulent ones. There must be sufficient in common between the two phenotypes determining the metric for selection in one environment to be relevant to expression in the other. This point was brought out by Falconer and Latyszewski (1952) and by Stino and Washburn (1973). Falconer and Latyszewski selected for growth rate on restricted ad libitum feeding. Their experiments could be interpreted as having selected for appetite on one diet and efficiency of food utilisation on the other. The latter proved of use in increasing growth rate on restricted diets, the former was quite ineffective in improving growth rate on restricted diets. It would be fallacious to take this as a refutation of Hammond's idea, since it is clear that selection has not been for one character in two environments but for two characters, one in one and one in the other. It is a demonstration of the danger of assuming that a given metric, in this case weight, is the same thing physiologically in all circumstances.

A further complication has been suggested by Jinks and Connolly (1973) who have brought forward evidence to show that " up " selection in a good environment will not exclude genes sensitive to a bad environment whereas up selection in a bad environment will. Hence up selection in a good environment and down selection in a bad one will tend to give rise to lines more sensitive to environmental change than down selection in a good and up selection in a bad environment.

It is apparent that the practical breeder must not be given any advice with the suggestion that it is universally applicable. He must be encouraged to observe and analyse each case on its merits, understand the physiology behind the metric he uses and choose the most appropriate selection technique for the character he wants to change. 


\title{
REFERENCES
}

DADAY, H. 1965. Aust. Fl. Ag. Res., 16, 293-299.

DADAY, H., BINET, F. E., GRASSIA, A., AND PEAK, J. W. 1973. Heredity, 31, 293-308.

FALCONER, D. S., AND LATYSZEWSKI, M. 1952. J. Genetics, 51, 67-80.

JINKs, J. L., AND CONNOLLY, v. 1973. Heredity, 30, 33.

SOBEy, w. R. 1969. 7. Hyg. Camb., 67, 743-753.

STINO, AND WASHBURN. 1973. Genetics, 74, 363-369.

Waddington, G. H. 1952. Nature, 169, 278-279.

\section{PRECURSORS AND GENETIC CONTROL OF PIGMENTATION}

\section{INDUCED BIOSYNTHESIS OF PELARGONIDIN, CYANIDIN AND DELPHINIDIN IN ANTIRRHINUM MAJUS}

\author{
R. G. STICKLAND and B. J. HARRISON \\ John Innes Institute, Colney Lane, Norwich NOR 7OF
}

Received 19.ii.74

\section{SUMMary}

Anthocyanidins have been synthesised in various acyanic genotypes of Antirrhinum majus following the administration of three dihydroflavonols.

\section{INTRODUCTION}

THE pathway of biosynthesis of flavonoids is now believed to be that outlined in fig. 1 (Harborne, 1967; Grisebach, 1972). The first flavonoid formed from cinnamic acid derivatives is flavanone (dihydroflavone). Introduction of an hydroxyl group in the 3-position gives the flavanonol (dihydroflavonol), which it is postulated rearranges to the flavenol, and this, by losing an $\mathrm{OH}^{-}$, can form anthocyanidin. Flavone and flavonol can be formed by oxidation of the corresponding dihydro-compounds. Flavanone can also

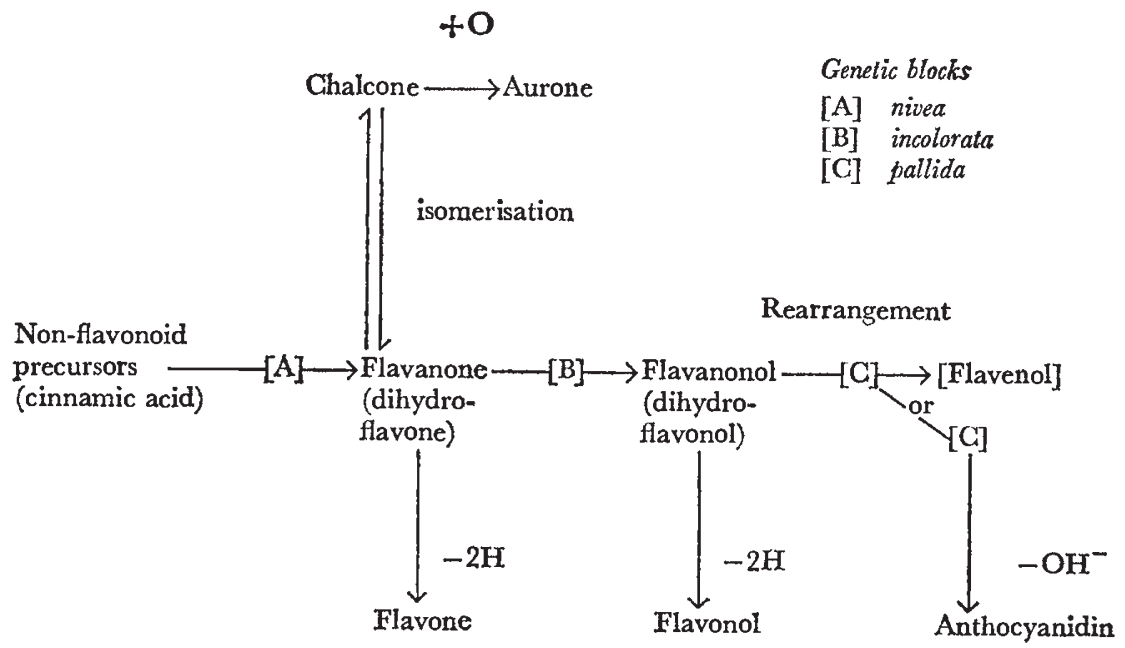

FIG. 1 